\title{
ANALISIS FAKTOR SOSIAL EKONOMI YANG MEMPENGARUHI PRODUKSI PETANI KOPI SANGGABUANA DI KECAMATAN TEGALWARU
}

\section{ANALYSIS OF SOCIAL ECONOMIC FACTORS AFFECTING PRODUCTION OF SANGGABUANA COFFEE FARMERS IN TEGALWARU DISTRICT KARAWANG REGENCY}

\author{
Rusmawati Utami*, Abubakar, I Putu Eka Wijaya \\ Program Studi Agribisnis Universitas Singaperbangsa Karawang. Jl. HS. Ronggo Waluyo, \\ Puseurjaya, Kec. Telukjambe, Kab. Karawang, Jawa Barat \\ *E-mail: rusmawatiu@gmail.com \\ (Diterima 03-01-2022; Disetujui 27-01-2022)
}

\begin{abstract}
ABSTRAK
Kabupaten Karawang memiliki potensi dalam produksi kopi yang ditunjukan oleh meningkatnya luas lahan di tahun 2018 dan 2019 sebesar 0,024 ha dengan nilai produksi sebesar 207,20 ton di tahun yang sama dengan nilai produktivitas Karawang sebesar 0,50 dibandingkan dengan daerah Pangandaran yang mengalami penurunan luas lahan sebesar 12,14 ha, dan memiliki nilai produksi yang meningkat yaitu dari tahun 2018 hingga 2019 sebesar15,60 ton dengan nilai produktivitas sebesar 0,44. Rendahnya produksi kopi di Kecamatan Tegalwaru dikarenakan petani yang membudidayakan kopi masih bersifat sederhana seperti tidak adanya perawatan pada tanaman, tidak dilakukan pemberian pupuk dan juga pestisida sehingga perlu adanya penelitian mengenai faktor sosial ekonomi terhadap produksi di Kecamatan Tegalwaru Kabupaten Karawang. Tujuan penelitian ini yaitu untuk mengetahui pengaruh secara parsial dan simultan faktor sosial ekonomi yang mempengaruhi produksi kopi. Sampel ditentukan dengan menggunakan rumus slovin, pengambilan sampel menggunakan metode simple random sampling. Teknik analisis yang digunakan adalah analisis regresi berganda, uji asumsi klasik dan uji hipotesis. Hasil penelitian menunjukan bahwa uji hipotesis secara simultan variabel independent (luas lahan, tenaga kerja, umur, lama usahatani, jumlah tanggungan, dan pendidikan) bersama-sama berpengaruh terhadap variabel dependen (produksi). Pada uji parsial hanya variabel luas lahan yang berpengaruh terhadap produksi.
\end{abstract}

Kata kunci : Kopi, Produksi, Sanggabuana

\begin{abstract}
Karawang Regency has potential in coffee production, this is shown by the increase in land area in 2018 and 2019 by 0.024 ha with a production value of 207.20 tons in the same year with a productivity value of 0.50 Karawang compared to the Pangandaran area which experienced a decline. land area of 12.14 ha and has an increased production value from 2018 to 2019 of 15.60 tons with a productivity value of 0.44. The low coffee production in Tegalwaru District is because farmers who cultivate coffee are still simple, such as the absence of plant care, no fertilizer and pesticides are applied, it is necessary to research on socio-economic factors on production in Tegalwaru District, Karawang Regency. The purpose of this research is to determine the partial and simultaneous influence of socio-economic factors that affect coffee production. Samples were determined using the Slovin formula, sampling using themethod simple random sampling. The analysis technique used is multiple regression analysis, classical assumption test and hypothesis testing. The results showed that the simultaneous hypothesis testing of independent variables (land area, labor age, length of farming, number of dependents, and education) jointly affected the dependent variable (production). In the partial test, only the land area variable has a partial effect on production.
\end{abstract}

Keywords: Coffee, Production, Sanggabuana 


\section{PENDAHULUAN}

Kopi merupakan salah satu komoditi hasil perkebunan yang mempunyai peran cukup penting dalam kegiatan perekonomian di Indonesia. Kopi merupakan salah satu komoditas ekspor di Indonesia yang cukup penting dalam penghasil devisa negara selain kelapa sawit dan karet. Luas areal lahan kopi pada tingkat provinsi pada tahun 2016 hinggal 2020 mengalami peningkatan, pada tahun 2016 sebesar 1.246.657 ha, tahun 2017 sebesar 1.238.598 ha, tahun 2018 sebesar 1.252.826 ha, tahun 2019 sebesar 1.258.032 dan pada tahun 2020 luas areal lahan kopi sebesar 1.264.331 ha. Pada tahun 2016 hingga 2017 mengalami penurunan luas areal lahan sebesar 8.059 ha (Direktorat Jendral Perkebunan, 2018). Luas lahan merupakan salah satu faktor yang mempengaruhi produksi. Semakin luas lahan maka hasil produksi semakin bertambah. Sebaliknya, jika luas lahan semakin sempit maka hasil produksi semakin sedikit (Onibala dan Sondakh, 2017). Hal ini ditunjukan oleh jumlah produksi kopi di Indonesia dari tahun 2016 hingga 2020 produksi kopi di Indonesia mengalami peningkatan yang cukup signifikan pada tahun 2016 jumlah hasil produksi mencapai 663.871 ton,
2017 sebesar 717.962 ton, 2018 sebesar 756.051 ton, 2019 sebesar 760.962 ton, dan pada tahun 2020 produksi kopi sebesar 773.409 ton (Direktorat Jendral Perkebunan, 2018).

Kabupaten Karawang merupakan salah satu daerah yang membudidayakan komoditas kopi dengan varietas kopi yaitu Robusta. Daerah Karawang yang berlokasi di Kecamatan Tegalwaru memiliki salah satu komoditas kopi yang khas yaitu Kopi Sanggabuana. Kopi ini merupakan salah satu tanaman khas yang tumbuh di Pegunungan Sanggabuana di mana kopi Sanggabuana memiliki rasa yang berbeda dengan kopi lainnya. Jika dibandingkan dengan daerah pangandaran yang memiliki kopi yang khas dan membudidayakan varietas robusta, produksi karawang lebih kecil dibandingkan daerah Pangandaran. Pada tahun 2018 hingga 2019 daerah Pangandaran mengalami kenaikan produksi sebesar 15,60 ton dari 253,00 ton menjadi 268,60 ton walaupun di tahun 2019 Pangandaran mengalami penurunan luas lahan sebesar 12,14 ha dari 609,29 ha menjadi 597,15 ha. Karawang memiliki hasil produksi yang sama di tahun 2018 hingga 2019 yaitu sebesar 207,20 ton, namun pada tahun 2018 hingga 2019 Karawang mengalami 
kenaikan pada luas lahan sebesar 0,024 ha dari 410.276 ha menjadi 410.300 ha (BPS Jawa Barat, 2020). Pada nilai produktivitas kopi daerah Karawang memiliki nilai produktivitas yang stagnan yaitu pada tahun 2018 dan 2019 sebesar 0,50. Nilai produktivitas pada daerah pangandaran mengalami peningkatan nilai produktivitas yaitu pada tahun 2018 sebesar 0,41 dan pada tahun 2019 sebesar 0,44 . Jika dilihat dari nilai produktivitas Karawang lebih unggul untuk berproduksi atau memiliki kemampuan dalam berproduksi lebih besar. Rendahnya produksi kopi di Tegalwaru dikarenakan petani yang membudidayakan kopi masih bersifat sederhana seperti tidak adanya perawatan pada tanaman kopi, tidak dilakukannya pemberian pupuk, dan pestisda. Harga jual kopi menjadi faktor yang dapat mempengaruhi produksi dikarenakan harga jual buah kopi dihargakan sebesar Rp2.000 - Rp3.000 per kilogram dimana harga ini termasuk kecil untuk petani kopi. Faktor modal juga mempengaruhi produksi kopi petani sanggabuana dikarenakan petani tidak memiliki modal untuk membeli pestisida dan juga untuk membeli teknologi guna meningkatkan nilai produksi. Oleh karena itu, tujuan penelitian ini untuk mengetahui faktor sosial ekonomi yang mempengaruhi produksi petani kopi Sanggabuana di Kecamatan Tegalwaru Kabupaten Karawang.

\section{METODE PENELITIAN}

Metode penelitian yang digunakan dalam penelitian ini yaitu metode penelitian kuantitatif dengan pendekatan deskriptif dimana metode ini merupakan salah satu jenis penelitian yang memiliki spesifikasi yaitu sistematis, terencana, dan terstruktur. Tempat penelitian ditentukan secara sengaja (purposive) yaitu di Kecamatan Tegalwaru Kabupaten Karawang.

Populasi pada penelitian ini sebanyak 426 (Dinas Petanian Karawang, 2021). Penentuan sampel menggunakan metode simple random sampling (acak sederhana) dengan jumlah sampel petani yang membudidayakan kopi, pemilihan sampel dengan diundi yang mana pada tiap anggota pada populasi memiliki kesempatan yang sama untuk terpilih menjadi sampel. Jumlah sampel ditentukan menggunakan rumus slovin sebagai berikut :

$$
\begin{gathered}
\mathrm{n}=\frac{\mathrm{N}}{1+\mathrm{N}(\mathrm{e})^{2}} \\
n=\frac{426}{1+426(0,15)^{2}}=40,24 \approx 40
\end{gathered}
$$




\section{ANALISIS FAKTOR SOSIAL EKONOMI YANG MEMPENGARUHI PRODUKSI PETANI KOPI \\ SANGGABUANA DI KECAMATAN TEGALWARU \\ Rusmawati Utami, Abubakar, I Putu Eka Wijaya}

Penelitian ini menggunakan metode analisis regresi berganda dengan menggunakan fungsi Cobb-Douglas dimana untuk mengetahui hubungan antara produksi dan faktor yang

mempengaruhi (Arifin et. al, 2019) dengan model fungsi produksi sebagai berikut:

$\mathrm{Y}=\mathrm{aX}_{1}^{\mathrm{b} 1} \mathrm{X}_{2}^{\mathrm{b} 2} \mathrm{X}_{3}^{\mathrm{b} 3} \mathrm{X}_{4}^{\mathrm{b} 4} \mathrm{X}_{5}^{\mathrm{b} 5} \mathrm{X}_{6}^{\mathrm{b} 6} \mathrm{e}$

Persamaan di atas dapat diubah menjadi bentuk linear berganda dengan melogaritmakan dalam bentuk logaritma natural (ln) dengan persamaan sebagai berikut :

$\operatorname{Ln} \mathrm{Y}=\operatorname{Ln} \alpha+\beta_{1} \operatorname{Ln} \mathrm{X}_{1}+\beta_{2} \operatorname{Ln} \mathrm{X}_{2}+$ $\beta_{3} \operatorname{Ln} \mathrm{X}_{3}+\beta_{4} \operatorname{Ln} \mathrm{X}_{4}+\beta_{5} \operatorname{Ln} \mathrm{X}_{5}+\beta_{6} \operatorname{Ln} \mathrm{X}_{6}$ $+\mathrm{e}$
Keterangan :

$\mathrm{X}_{1}=$ Luas lahan $(\mathrm{Ha})$

$\mathrm{X}_{2} \quad=$ Tenaga kerja (Hko)

$\mathrm{X}_{3} \quad=$ Umur (Tahun)

$\mathrm{X}_{4} \quad=$ Lama usahatani (Tahun)

$\mathrm{X}_{5}=$ Jumlah tanggungan (Orang)

$\mathrm{X}_{6} \quad=$ Pendidikan

$\mathrm{Y} \quad=$ Produksi kopi (ton)

\section{HASIL DAN PEMBAHASAN}

\section{Karakteristik Responden}

Karakteristik responden pada penelitian ini yaitu luas lahan, tenaga kerja, umur, lama usahatani, jumlah tanggungan, dan pendidikan dapat dilihat pada Tabel 1.

Tabel 1. Karakteristik Responden

\begin{tabular}{|c|c|c|c|c|c|}
\hline No & Karakteristik & Satuan & Uraian & Jumlah (orang) & $\%$ \\
\hline \multirow[t]{4}{*}{1.} & Luas lahan & $\mathrm{Ha}$ & $0.3-1.2$ & 26 & 65,00 \\
\hline & & & $1.3-2.2$ & 9 & 22,50 \\
\hline & & & $2.3-3.2$ & 3 & 7,50 \\
\hline & & & $3.3-4.2$ & 2 & 5,00 \\
\hline \multirow[t]{3}{*}{2.} & Tenaga kerja & $\mathrm{HOK}$ & $3-10$ & 16 & 40,00 \\
\hline & & & $11-17$ & 19 & 47,50 \\
\hline & & & $18-24$ & 5 & 12,50 \\
\hline \multirow[t]{6}{*}{3.} & Umur & Tahun & $25-33$ & 7 & 17.50 \\
\hline & & & $34-42$ & 15 & 37,50 \\
\hline & & & $43-51$ & 11 & 27,50 \\
\hline & & & $52-60$ & - & - \\
\hline & & & $61-69$ & 5 & 1250 \\
\hline & & & $70-78$ & 2 & 5,00 \\
\hline \multirow[t]{5}{*}{4.} & Lama usahatani & Tahun & $4-7$ & 18 & 45,00 \\
\hline & & & $8-11$ & 13 & 32,50 \\
\hline & & & $12-15$ & 6 & 15,00 \\
\hline & & & $16-19$ & 1 & 2,50 \\
\hline & & & $20-23$ & 2 & 5,00 \\
\hline \multirow[t]{3}{*}{5.} & Jumlah tanggungan & Orang & 1- 2 & 10 & 25,00 \\
\hline & & & $3-4$ & 28 & 70,00 \\
\hline & & & $5-6$ & 2 & 5,00 \\
\hline \multirow[t]{3}{*}{6.} & Pendidikan & Tahun & $\mathrm{SD}$ & 30 & 75,00 \\
\hline & & & SMP & 7 & 17,50 \\
\hline & & & SMA & 3 & 7,50 \\
\hline
\end{tabular}

Sumber : Analisis Data Primer, 2021 
Faktor-faktor yang Mempengaruhi

\section{Produksi Kopi}

Penelitian ini menggunakan analisis regresi berganda untuk mengetahui pengaruh variabel independen $\mathrm{X}$ terhadap variabel dependen (Y). Variabel independen yang digunakan yaitu :

1. Produksi (Y) merupakan banyaknya jumlah kopi yang dihasilkan dalam satu tahun dari faktor-faktor yang mempengaruhi produksi kopi dinyatakan dengan ton.

2. Luas lahan $\left(\mathrm{X}_{1}\right)$ merupakan luasan garapan yang dibudidayakan oleh petani untuk melaksanakan usahataninya dalam luasan tertentu dan dinyatakan dalam satuan hektar (Ha).

3. Tenaga kerja $\left(\mathrm{X}_{2}\right)$ merupakan tenaga pembantu petani yang dapat berasal dari luar keluarga maupun dari dalam keluarga guna menghasilkan suatu barang atau jasa untuk mengolah bahan baku menjadi produk dihitung dalam satuan HOK.

4. Umur $\left(\mathrm{X}_{3}\right)$ merupakan perhitungan usia yang dimulai petani memulai berusahatani kopi usia dinyatakan dalam satuan tahun lama usahatani $\left(\mathrm{X}_{4}\right)$,

5. Jumlah tanggungan $\left(\mathrm{X}_{5}\right)$ merupakan lamanya petani dalam menjalankan usahatani kopi dinyatakan dengan tahun.

6. Pendidikan $\left(\mathrm{X}_{6}\right)$ merupakan jenjang pendidikan yang ditempuh oleh petani, diukur dengan skala ordinal.

Sebelum melakukan analisis regresi perlu adanya melakukan uji asumsi klasik yang terdiri dari uji normalitas, uji autokorelasi, uji multikolinieritas, uji heteroskdastisitas, dan uji linieritas. Hasil analisis tersebut diperoleh bahwa:

1) Uji Normalitas, pada uji ini untuk melihat apakah data berdistribusi normal atau tidak. Pada hasil uji normalitas nilai Asymp. Sig (2-tailed) sebesar 0,200 atau $>0,05$ hal ini bahwa nilai residual terstandarisasi dinyatakan menyebar secara normal.

2) uji autokorelasi, bertujuan untuk mengetahui apakah ada korelasi pada model regresi. Hasil uji autokorelasi yaitu nilai durbin watson sebesar 2,089 dimana pengambilan keputusan $\mathrm{dU}<\mathrm{dw}<4-\mathrm{dU}$, nilai dU diperoleh tabel dw ( $\alpha=5 \%)$ sebesar 1,8538 dan 4-dU sebesar 2,1462 dimana nilai dw yaitu 2,089 terletak diantara dU dengan 4-dU dimana tidak terjadinya autokorelasi.

3) Uji multikolinieritas, yang bertujuan untuk meguji apakah dalam model regresi yang terbentuk ada korelasi 
yang tinggi atau sempurna diantara variabel bebas atau tidak. Pada uji ini melihat nilai TOL (tolerance) $>0,10$ dan VIF (Variance Infletion Factor) < 10,00. Pada hasil tolerance sebesar 0,458 - 0,903 dimana hasil ini > 10,00 dan nilai VIF sebesar 1,107 2,185 dimana hasil ini $<10,00$ maka tidak terjadi multikolinieritas.

4) Uji heteroskedastisitas

Uji ini bertujuan menguji apakah di dalam model suatu regresi terjadi ketidaksamaan varian dari residual satu pengamatan ke pengamatan yang lain. Hasil signifikansi sebesar 0,155 hingga 0,892 dimana $>0,05$ maka tidak memiliki masalah heteroskedastisitas.

5) Uji linieritas

Uji linieritas menggunakan metode ramsey. Metode ini mencari nilai $\mathrm{R}^{2}$ old dengan $\mathrm{R}^{2}$ new dilihat pada tabel Model Summary dari hasil output SPSS. Hasil output spss yaitu:

$$
\begin{gathered}
F=\frac{\left(R^{2} \text { New }-R^{2} \text { Old }\right) / m}{\left(1-R^{2} N e w\right) /(n-k)} \\
F=\frac{(0,980-0,869) / 1}{(1-0,0980) /(40-6)}=188,7
\end{gathered}
$$

Maka dapat disimpulkan F hitung $(188,7)>\mathrm{F}$ tabel $(2,450)$ pada model regresi dinyatakan linier.

\section{Uji Hipotesis}

Berdasarkan hasil pengujian hipotesis pada Tabel 2. diperoleh hasil regresi berganda dengan fungsi CobbDouglas sebagai berikut:

$$
\begin{aligned}
& \operatorname{LnY}=6,600+1,013 \operatorname{LnX} 1-0,071 \operatorname{LnX}_{2}+ \\
& 0,119 \operatorname{LnX}_{3}+0,043 \operatorname{LnX}_{4}-0,058 \operatorname{LnX}_{5}- \\
& 0,019 \operatorname{LnX}_{6}
\end{aligned}
$$

Hasil $\mathrm{R}^{2}$ atau koefisien determinasi sebesar 0,869 berarti bahwa variabel produksi dapat dijelaskan oleh variabel luas lahan, tenaga kerja, umur, lama usahatani, jumlah tanggungan dan pendidikan sebesar $86,9 \%$.

\section{Uji F (bersama-sama)}

Berdasarkan hasil output di atas nilai signifikan sebesar 0,000 dimana sig $<0,05$ dimana sesuai dengan pengambilan keputusan jika nilai signifikan $<0,05$ maka variabel independen secara bersama-sama berpengaruh terhadap variabel dependen.

\section{Uji t (masing-masing)}

Uji parsial dilakukan dengan membangdingkan nilai $\alpha$ (alpha) dengan nilai signifikan. Jika nilai signifikan < nilai $\alpha$, maka $\mathrm{H}_{0}$ ditolak. Sehingga dapat diambil kesimpulan memiliki pengaruh secara parsial antara variabel independen dengan variabel dependen, dan sebaliknya. Berdasarkan pada Tabel 2. hanya variabel luas lahan yang 
berpengaruh secara parsial terhadap produksi kopi sanggabuana. Penjelasan hasil uji t sebagai berikut:

\section{a. Koefisien $X_{1}($ Luas lahan $)=1,013$}

Hasil koefiesien luas lahan memiliki pengaruh positif yang berarti jika luas lahan mengalami peningkatan sebesar $1 \%$, sementara tenaga kerja, umur, lama usahatani, jumlah tanggungan dan tingkat pendidikan dianggap tetap, maka akan menyebabkan kenaikan produksi Kopi Sanggabuana sebesar 1,013\%.

\section{b. Koefisien $\mathrm{X}_{2}($ Tenaga kerja $)=\mathbf{- 0 , 0 7 1}$}

Hasil koefisien tenaga kerja menunjukan hasil negatif yang berarti jika tenaga kerja mengalami peningkatan sebesar $1 \%$, sementara luas lahan, umur, lama usahatani, jumlah tanggungan, dan pendidikan dianggap tetap, maka akan menyebabkan penurunan sebesar 0,071\% pada produksi Kopi Sanggabuana. Pada penelitian di lapangan tenaga kerja tidak berpengaruh terhadap hasil produksi kopi dikarenakan tenaga kerja yang dipekerjakan tidak terampil dalam budidaya tanaman kopi.

\section{c. Koefisien $X_{3}($ Umur $)=0,119$}

Koefisien umur menunjukan hasil positif yang berarti apabila umur mengalami peningkatan sebesar $1 \%$, sementara luas lahan, tenaga kerja, lama usahatani, jumlah tanggungan dan pendidikan dianggap tetap, maka menyebabkan kenaikan produksi kopi sebesar $0,119 \%$.

\section{d. Koefisien $\mathrm{X}_{4}$ (Lama usahatani) $=$} 0,043

Koefisien lama usahatani menunjukan hasil positif yang berarti apabila lama usahatani mengalami peningkatan sebesar $1 \%$, sementara luas lahan, tenaga kerja, umur, jumlah tanggungan keluarga, dan pendidikan tetap, maka akan menyebabkan kenaikan sebesar $0,043 \%$ pada produksi Kopi Sanggabuana.

e. Koefisien $\mathbf{X}_{5}$ (Jumlah tanggungan $)=$ $-0,058$

Koefisien jumlah tanggungan menunjukan hasil negatif yang berarti apabila jumlah tanggungan mengalami peningkatan sebesar $1 \%$, sementara nilai luas lahan, tenaga kerja, umur, lama usahatani dan pendidikan tetap, maka akan menyebabkan penurunan produksi kopi sebesar sebesar 0,0578\%. Hal ini dikarenakan semakin banyak jumlah tanggungan, maka petani akan menyisihkan pendapatan yang dihasilkan dari produksi untuk memenuhi kebutuhan tanggungan yang ditanggung oleh petani kopi. Artinya, petani akan menyisihkan pendapatannya dari hasil produksi untuk keperluan keluarga dibandingkan dengan 
kebutuhan untuk produksi seperti pupuk dan juga pestisida.

\section{f. Koefisien $X_{6}($ Pendidikan $)=\mathbf{- 0 , 0 1 9}$}

Koefisien pendidikan menunjukan hasil negatif yang berarti apabila tingkat pendidikan mengalami peningkatan sebesar $1 \%$, sementara luas lahan, tenaga kerja, umur, lama usahatani, dan jumlah tanggungan dianggap tetap, maka akan menyebabkan penurunan produksi sebesar 0,019\%. Semakin tinggi pendikan petani, maka penyerapan dalam penggunaan teknologi akan semakin baik, namun pada produksi Kopi Sanggabuana jika seseorang memiliki pendidikan yang cukup tinggi maka orang tersebut memilih untuk tidak berusahatani kopi dikarenakan hasil produksi yang tidak terlalu tinggi, maka mereka akan memilih pekerjaan yang lain.

Tabel 2. Hasil Regresi Produksi Kopi

\begin{tabular}{lrrr}
\hline \multicolumn{1}{c}{ Variabel } & $\begin{array}{c}\text { Koefisien } \\
\text { Regresi }\end{array}$ & thitung & Sig. \\
\hline Luas lahan & 1.013 & 10,359 & 0,000 \\
Tenaga kerja & $-0,071$ & $-0,669$ & 0,508 \\
Umur & 0,119 & 0,646 & 0,523 \\
Lama usahatani & 0,043 & 0,393 & 0,697 \\
Jumlah & $-0,058$ & $-0,0411$ & 0,683 \\
tanggungan & & & \\
Pendidikan & $-0,019$ & $-0,151$ & 0,881 \\
\hline $\mathrm{R}^{2}$ & 0,869 & & \\
F sig. & 0,000 & & \\
\hline Sumber : Analin
\end{tabular}

Sumber : Analisis Data Primer, 2021

\section{KESIMPULAN DAN SARAN}

\section{Kesimpulan}

Berdasarkan pembahasan dapat disimpulkan bahwa semua variabel independent mempengaruhi produksi petani kopi secara bersama-sama. Pada uji parsial variabel luas lahan berpengaruh terhadap produksi petani Kopi Sanggabuana, pada faktor tenaga kerja, umur, lama usahatani, jumlah tanggungan dan pendidikan tidak berpengaruh terhadap produksi kopi.

\section{Saran}

Petani kopi hendaknya meningkatkan pemeliharaan dan perawatan pada tanaman kopi yang ditanam. Pohon kopi yang sudah dapat berbuah atau sudah berproduksi baiknya mendapatkan perlakuan yang baik guna dapat mengoptimalkan produksi buah kopi perlakuan tersebut meliputi, pemupukan, pemangkasan, dan juga memberikan pestisida. Peran penyuluh juga sangat diperlukan dalam produksi petani kopi hal yang dapat dilakukan seperti mengadakan penyuluhan, dan pembinaan mengenai peningkatan produksi kopi.

\section{DAFTAR PUSTAKA}

Arifin, M. Z., Mahfudz, M., dan Hindarti, S. 2019. Analisis Faktor-Faktor Sosial Ekonomi Yang Mempengaruhi Pendapatan Usahatani Padi Sawah Di Desa Sukorejo Kecamatan Sukorjo Kabupaten Ponorogo. Jurnal Sosial 
Ekonomi Pertanian dan Agribisnis, 7(1).

Amisan, R. E., Laoh, O. E. H., \& Kapantow, G. H. 2017. Analisis Pendapatan Usahatani Kopi di Desa Purwerejo Timur, Kecamatan Modayag, Kabupaten Bolaang Mongondow Timur. AgriSosioekonomi, 13(2A), 229-236.
Badan Pusat Statistika Jawa Barat. 2020. Provinsi Jawa Barat Dalam Angka. Jawa Barat.

Direktorat Jendral Perkebunan. 2018. Luas Areal Kopi Menurut Provinsi di Indonesia 2016-2020. Direktorat Perkebunan. Jakarta.

Onibala, A. G., dan Sondakh, M. L. 2017. Analisis faktor-faktor yang mempengaruhi produksi padi sawah di Kelurahan Koya, Kecamatan Tondano Selatan. AgriSosioekonomi, 13(2A), 237-242. 